\title{
OS CONTOS DE FADAS E A FORMAÇÃO DE VALORES MORAIS
}

\author{
FAIRY TALES AND THE MORAL VALUES FORMATION
}

\section{Dalva Ramos Resende Matos UFG / UFU / UFMT}

RESUMO: Os contos de fadas encantam os leitores por meio da fantasia e do maravilhoso, mas, ao mesmo tempo, eles também ajudam a criança a perceber o mundo e prestam suportes simbólicos para a formação de seus valores morais e éticos, pois abordam dilemas inerentes ao amadurecimento humano e exteriorizam os seus sentimentos mais profundos, dos mais sublimes aos mais primitivos. Sendo assim, este artigo trata-se de um estudo teórico-analítico sobre os contos de fadas e os valores morais, fundamentado à luz de pesquisas em diversas áreas, como Literatura, Psicologia e Psiquiatria. Inicialmente, será apresentada uma breve fundamentação teórica sobre esse gênero narrativo, abordando conceitos elementares e traçando um panorama da história sociocultural dessas narrativas. Em seguida, a título de ilustração, será feita uma breve análise das moralidades apresentadas por Perrault nos contos As Fadas e Cinderela. Vale ressaltar que o objetivo deste trabalho não é transformar os contos de fadas em um objeto funcional, mas sim colocar em pauta a contribuição deles para a formação dos valores das novas gerações, pois, segundo Walter Benjamin, esse gênero literário é hoje o conselheiro das crianças, porque foi antes o primeiro da humanidade.

PALAVRAS-CHAVE: Teoria literária; Psicanálise; Conto de fadas; Valores morais.

ABSTRACT: Fairy tales delight the readers through fantasy and wonderment, but, at the same time, they also help children understand the world and provide symbolic support for the formation of their moral and ethical values, because they handle dilemmas that are intrinsic to the human growth and externalize their deepest feelings, from the most primitive to the most sublime ones. Therefore, this article talks about a theoretical and analytical study of fairy tales and moral values, based on researches in many different fields such as Literature, Psychology and Psychiatry. Initially, it is shown a brief theoretical background on this narrative genre, handling basic concepts and drawing an overview of the sociocultural history of these narratives. Then, by way of illustration, a brief analysis of morals presented by Perrault in the tales "The fairies" and "Cinderella" is taken. It is noteworthy that the objective of this article is not to turn fairy tales into a functional object, but to highlight their contribution to the formation of the values of the younger generations, because, according to Walter Benjamin, this literary genre is currently the children's adviser, as it was the first of mankind.

KEYWORDS: Literary Theory; Psychoanalysis; Fairy tales; Moral values. 


\section{Revista do SELL \\ v. $4, n^{\circ} .2$ \\ ISSN: $1983-3873$}

\section{Introdução}

Em uma sociedade em que a aparência vale mais do que a essência, a competição e o individualismo prevalecem nos relacionamentos e os valores morais parecem ser progressivamente esquecidos, faz-se necessária a formação de valores básicos para a vida e a convivência em uma sociedade plural e democrática (CHALITA, 2003).

Nesse contexto, segundo Antonio Candido, a literatura pode contribuir com o seu poder humanizador para que o leitor seja levado, ainda que de maneira inconsciente, a buscar, na leitura literária, a reflexão, a sabedoria, a boa disposição para com o próximo, o afinamento das emoções, a capacidade de penetrar nos problemas da vida, a compreensão da complexidade do mundo e dos seres. Segundo esse autor: "A literatura desenvolve em nós a quota de humanidade na medida em que nos torna mais compreensivos e abertos para a natureza, a sociedade, o semelhante" (CANDIDO, 1995, p. 249).

Sob esse prisma do aspecto humanizador da literatura, os contos de fadas podem auxiliar e muito na tarefa de construção da personalidade infantil, pois mais do que qualquer outro tipo de narrativa, eles dirigem a criança para a descoberta de sua identidade e também sugerem as experiências que são necessárias para desenvolver o seu caráter. Nesses contos infantis, encontram-se o amor, os medos, as dificuldades de ser criança, as carências (afetivas e materiais), as autodescobertas, as perdas, as buscas, a solidão, a imoralidade das personagens malévolas e as virtudes dos heróis e heroínas.

Como obra de arte, esses contos encantam a todos por meio do lúdico, da fantasia, dos significados psicológicos e contribuem, de forma efetiva, para a educação moral da criança. Dessa forma, ao mesmo tempo em que essas narrativas encantam as crianças com o prazer literário, também ensinam. Não um saber institucionalizado, mas uma sabedoria de vida, pois ajudam as crianças a perceberem o mundo e prestam suportes simbólicos para a formação de seus valores morais e éticos, abordando dilemas inerentes ao amadurecimento humano e exteriorizando os sentimentos mais profundos, dos mais sublimes aos mais primitivos.

Assim sendo, lições de moral como a humildade da Cinderela, a paciência da Bela Adormecida, a pureza da Branca de Neve, a exaltação da beleza interior em A Bela e a Fera e outros sentimentos como o amor, a fraternidade e a bondade, manifestados por heróis e heroínas dos diversos contos de fadas, vão ao encontro dos anseios infantis de 


\section{Revista do SELL}

v. $4, n^{\circ} .2$

ISSN: $1983-3873$

corresponder a uma imagem do bem que sempre vence no final. Em contrapartida, sentimentos como a inveja, o ódio, a cobiça, a desobediência, o egoísmo e a vingança, exteriorizados simbolicamente no perfil de personagens do mal - como bruxas, madrastas cruéis e irmãs invejosas - são rejeitados.

Os contos de fadas são tão ricos que têm sido fonte de estudo para psicanalistas, sociólogos, antropólogos, linguistas, críticos literários e outros especialistas, cada qual dando sua interpretação e aprofundando no seu eixo de interesse. Neste trabalho, o olhar será voltado para a contribuição dessas narrativas para a formação dos valores morais e éticos das crianças, por meio de um estudo teórico-analítico dos contos de fadas. Para isso, inicialmente, serão apresentados os resultados de uma pesquisa bibliográfica sobre esse gênero narrativo, explicitando conceitos elementares e mostrando um panorama da história sociocultural das origens dessas narrativas às produções modernas. Em seguida, a título de ilustração, será feita uma breve análise das moralidades apresentadas por Perrault nos contos As Fadas e Cinderela.

Sabe-se que o tema deste artigo é palco de divergências entre especialistas de várias áreas. Por isso, ressalta-se que o objetivo deste trabalho não é reduzir o conto de fadas a um objeto funcional, muito menos uma tentativa de atribuir utilidade a todo custo para a literatura, uma vez que o maior encantamento desse gênero narrativo reside no maravilhoso, na fantasia, na arte literária. O próprio Bruno Bettelheim, em sua obra $A$ psicanálise dos contos de fadas, destaca que:

O prazer que experimentamos quando nos permitimos ser suscetíveis a um conto de fadas, o encantamento que sentimos não vêm do significado psicológico de um conto (embora isto contribua para tal) mas de suas qualidades literárias - o próprio conto como uma obra de arte. O conto de fadas não poderia ter seu impacto psicológico sobre a criança se não fosse antes de tudo uma obra de arte. (BETTELHEIM, 1992, p.20).

Também é possível afirmar que o conto de fadas é constituído de forma e conteúdo ordenados com a finalidade de impressionar e causar sentimentos relacionados às virtudes morais, bem como suscitar comoção, indignação, alegria e superação. Por isso, o "[...] maravilhoso, concretizado em imagens, metáforas, símbolos, alegorias... é o mediador, por excelência, dos valores a serem individualmente assimilados pelos ouvintes ou leitores (para além do puro prazer que sua linguagem possa transmitir...)." (COELHO, 1984, p. 23, grifo do autor). 


\section{Revista do SELL}

v. $4, n^{\circ} .2$

ISSN: $1983-3873$

\section{O maravilhoso, o conto de fadas e as fadas}

No universo do maravilhoso, o gênero "conto de fadas" tem sido utilizado para designar histórias provenientes da oralidade, com ou sem presença de fadas, que se passam em um tempo e espaço indeterminados, tendo como núcleo as ações de um herói ou uma heroína que empreende uma trajetória difícil, permeada de provas, cuja superação leva ao sucesso final. A presença do "maravilhoso" é fundamental nessas narrativas, pois, na trajetória do(a) protagonista, são os meios mágicos que the possibilitam ultrapassar as difíceis provas qualificadoras. (COELHO, 1987)

De maneira geral, os gêneros conto maravilhoso, conto de fadas e conto exemplar vêm sendo tratados como sinônimos. Porém, Coelho (2003) explica que há entre eles uma diferença essencial em função da problemática que thes serve de fundamento. Segundo essa autora, o conto maravilhoso tem raízes orientais, não há, nele, a presença de fadas e seu enredo gira em torno de uma problemática material-social-sensorial, ou seja, parte de um ambiente de miséria e está ligada à realização socioeconômica (a busca de riquezas; a conquista de poder; a satisfação do corpo, etc.) do indivíduo no seu meio. Exemplos: Aladim e a Lâmpada Maravilhosa; O Gato de Botas; Ali Babá e os Quarenta Ladrões. Já o conto de fadas tem origens célticas. Com ou sem a presença de fadas (mas sempre com o maravilhoso), seus argumentos desenvolvem-se dentro da magia feérica (reis, rainhas, príncipes, princesas, fadas, bruxas, gigantes, objetos mágicos, metamorfoses, tempo e espaço fora da realidade conhecida...) e o enredo gira em torno de uma problemática espiritual-ética-existencial ligada à autorrealização do indivíduo, seja por meio do encontro do seu verdadeiro "eu" ou pela união matrimonial do Cavaleiro com a Amada (princesa ou plebeia), como: Rapunzel; Cinderela; Branca de Neve e os Sete Anões; A Bela e a Fera. Já os contos exemplares misturam as duas problemáticas: a social e a existencial, como Chapeuzinho Vermelho; O Pequeno Polegar; João e Maria.

Quanto ao termo "fada", etimologicamente, vem do latim fatum que significa destino, fatalidade, oráculo. Segundo Coelho (1987), as fadas tornaram-se conhecidas como seres fantásticos ou imaginários de grande beleza, que se apresentavam sob a forma de mulher. Dotadas de virtudes e poderes sobrenaturais, interferem na vida dos homens para auxiliá-los em situações-limite, quando mais nenhuma solução natural seria possível. Mas, elas podem também ser más e vingativas como a fada que pune os pais 


\section{Revista do SELL}

v. $4, n^{\circ} .2$

ISSN: $1983-3873$

da Bela Adormecida. Geralmente, estas últimas trazem uma ligação íntima com as forças diabólicas e são conhecidas como bruxas ou feiticeiras.

No dizer da escritora infantil Kátia Canton, a explicação para o termo "conto de fadas", a despeito de nem todas as histórias apresentarem fadas, seria uma maneira de marcar um tipo de conto.

Fadas foram criadas para diferenciar os contos de gente rica, que vivia perto do rei, dos contos dos pobres, que moravam no campo. Personagens mágicas, com roupas de tule branco, chapéus pontiagudos e varinhas de condão, as fadas faziam um modelito na França do século 17, do mesmo modo como o estilo punk ficou na moda nos anos 80. (CANTON, 1997, p.15).

Assim sendo, o que caracteriza esses contos não é a presença ou a ausência do elemento "fadas". Para Todorov, o que distingue o conto de fadas não é o estatuto do sobrenatural, mas sim uma certa escritura.

No caso do maravilhoso, os elementos sobrenaturais não provocam qualquer reação particular nem nas personagens nem no leitor implícito. Não é uma atitude para com os acontecimentos que caracteriza o maravilhoso, mas a própria natureza desses acontecimentos. Os contos de fadas, a ficção científica são algumas variedades do maravilhoso; mas eles já nos levam longe do fantástico. (TODOROV, 1979, p. 160).

Em relação à estrutura narrativa, os contos de fadas iniciam-se com um problema vinculado à realidade (estado de penúria, carência afetiva, conflito entre mãe e filho) que desequilibra a tranquilidade inicial. O desenvolvimento é uma busca de soluções, no plano da fantasia, com a introdução de elementos mágicos (fadas, bruxas, anões, duendes, gigantes, talismãs etc.). A ordem é restaurada quando acontece, no desfecho da narrativa, uma volta ao real. Por meio dessa estrutura fixa, "[...] os autores, de um lado, demonstram que aceitam o potencial imaginativo infantil e, de outro, transmitem à criança a ideia de que ela não pode viver indefinidamente no mundo da fantasia, sendo necessário assumir o real, no momento certo." (AGUIAR, apud ABRAMOVICH, 1989, p. 120).

O desfecho é, geralmente, do tipo "felizes para sempre". Para Cunha, o final feliz é importante, uma vez que é um requisito essencial, sobretudo para as crianças mais novas.

Se o adulto é capaz de ler um livro ou ver um filme que acabe mal, sem deixar de apreciar o livro ou o filme, pelo aspecto puramente artístico, ou 


\section{Revista do SELL}

v. $4, n^{\circ} .2$

ISSN: $1983-3873$

pela realidade da vida neles apresentada, tal não se pode esperar da criança. Normalmente, ela vive a história, identifica-se com a personagem simpática, e o final desagradável a feriria inutilmente. (CUNHA, 1986, p. 77).

Essa autora não defende o final com a mais absoluta felicidade, mas acredita que a amargura não deveria ser desenvolvida no espírito infantil, uma vez que o leitor infantil ainda não sabe lidar com finais tristes para as personagens do bem. Ao ver seus problemas personificados por heróis e heroínas dos contos de fadas, a criança renova sua esperança de um futuro melhor quando o bem triunfa no final.

\section{Panorama da história sociocultural dos contos de fada: sob o prisma da moralidade}

Por serem de tradição oral, os contos de fadas perdem-se na memória dos tempos e os estudos atestam que a origem desse gênero é complexa e imprecisa. Provavelmente, esses contos são oriundos das narrativas primordiais que ensinavam aos homens como enfrentar os poderes divinos, controlar as forças da natureza e compreender os segredos da alma humana. As pesquisas mais recentes vêm ampliando o conhecimento das longas e emaranhadas trajetórias percorridas por essas narrativas arcaicas, até se transformarem na literatura folclórica em cada canto do planeta e nos contos de fadas para crianças.

Para a produção deste breve panorama histórico, buscou-se a maioria das informações em Coelho (1984, 1987, 2003) e não há, aqui, a preocupação de mostrar a trajetória exclusiva dos contos de fadas, uma vez que a história destes está associada a dos contos maravilhosos e dos contos exemplares. Além disso, no passado, não havia a distinção entre esses gêneros, nem mesmo por parte dos especialistas, as narrativas eram agrupadas por títulos genéricos. No Brasil e em Portugal, essas histórias surgiram, no fim do século XIX, como contos da carochinha, já o folclorista Câmara Cascudo denominou-as contos de encantamento. E a verdade é que mesmo hoje todas essas histórias são chamadas vulgarmente de contos de fadas ou contos maravilhosos.

Segundo Coelho (2003), dentre as descobertas mais importantes desenvolvidas por historiadores, antropólogos, filólogos, etnólogos e outros pesquisadores, está o cruzamento das várias pesquisas que acabou revelando as raízes desses contos de expansão popular: a fonte oriental (procedente da Índia, séculos antes de Cristo) que vai 


\section{Revista do SELL}

v. $4, n^{\circ} .2$

ISSN: $1983-3873$

se fundir, ao longo dos séculos, com a fonte latina (greco-romana) e com a fonte célticobretã (na qual originaram as fadas). Sabe-se, portanto, que os contos de fadas são de origem céltica, século II a.C., e surgiram como poemas que revelavam amores estranhos, fatais, eternos. Originalmente, foram concebidos como entretenimento para adultos e eram contados em reuniões sociais, nas salas de fiar, nos campos e em outros ambientes onde os adultos se reuniam. Para alguns estudiosos, não continham lições de moral e apresentavam fortes doses de incesto, canibalismo, estupro e adultério.

Contudo, a partir dos estudos filológicos e antropológicos, desenvolvidos na Alemanha a partir do século XVIII, visando estabelecer a "língua oficial alemã" em meio aos vários dialetos orais, descobriu-se que as narrativas ancestrais - contadas nos serões familiares ou "ao redor do fogo"- mais do que um mero entretenimento, eram valiosos instrumentos transmissores de valores de geração em geração, consolidando o Sistema de comportamentos consagrados por determinado grupo social (COELHO, 2003).

Como literatura destinada ao público infantil, historicamente, os contos de fadas tradicionais, bem como a Literatura Infantil, nasceram na França do séc. XVII na corte do rei Luís XIV pelas mãos do erudito Charles Perrault. Naquela época, o escritor reuniu narrativas orais na obra intitulada Histórias e Contos do tempo passado, com moralidades (1697), mais conhecida como Contos de Mamãe Gansa, e destinou essa coletânea às crianças, acrescentando-Ihes uma moralidade conveniente aos princípios educacionais da época. Nos contos registrados por Perrault, estão: A Bela Adormecida no Bosque, Cinderela, Henrique do Topete, O Gato de Botas, O Pequeno Polegar, As fadas, Chapeuzinho Vermelho e Barba Azul.

Segundo Benedetti (2012), a autoria desses contos publicados pela primeira vez em 1697 foi atribuída pelo próprio Charles Perrault a Pierre Darmancour, seu filho, que tinha então dezenove anos. O objetivo era escapar das críticas por parte de seus opositores na famosa polêmica entre os defensores dos antigos e os dos modernos. Somente partir de 1781, a obra passaria a ser definitivamente atribuída a Charles Perrault.

A origem dos textos utilizados por Perrault não é datada. Como tudo o que pertence à cultura popular, não tem paternidade nem certidão de nascimento. No entanto, seus contos estão impregnados da época em que foram fixados por escrito. Roupagens, costumes, conceitos e preconceitos são do século XVII. E assim fixados chegaram até nós. (BENEDETTI, 2012, p.13). 


\section{Revista do SELL}

v. $4, n^{\circ} .2$

ISSN: $1983-3873$

Algumas dessas narrativas foram recontadas pelos Irmãos Grimm, Jacob (17851863) e Wilhelm (1786 - 1859), filólogos, folcloristas, estudiosos da mitologia germânica, que viajaram, no século XIX por todas as regiões de língua alemã, coletando, da memória popular, antigas narrativas maravilhosas, lendas e sagas que transcreviam à noite. Esse fantástico material foi usado de forma sensível e com preocupação de estilo, conservando a ingenuidade popular, a fantasia e o poético em uma coletânea conhecida hoje como Literatura Clássica Infantil. Dentre os contos mais conhecidos estão: A Bela Adormecida, Branca de Neve e os Sete Anões, A Gata Borralheira, Chapeuzinho Vermelho, Rapunzel, João e Maria e dezenas de outras histórias maravilhosas que correm 0 mundo. Inicialmente foram publicadas avulsamente entre 1812 e 1822, e mais tarde reunidas no volume Contos de fadas para crianças e adultos, conhecido também como Contos de Grimm.

É importante ressaltar que, influenciados pelo espírito cristão que se firmava na época romântica e cedendo à polêmica levantada por alguns intelectuais contra a crueldade de certos contos, os Grimm foram retirando episódios de demasiada violência e crueldade das várias edições de suas publicações ao longo dos anos. Assim, o públicoalvo foi mudando e a edição compacta, de 1825, reunia apenas histórias maravilhosas de cunho educativo voltadas especificamente para as crianças.

O acervo da Literatura Infantil Clássica seria completado anos depois com os Eventtyr, 168 contos publicados entre 1835 e 1877 pelo dinamarquês Hans Christian Andersen (1805 -1875). Filho de sapateiro e lavadeira, Andersen obteve fama ainda vivo. Sua vida foi como seus contos de fadas, onde meninos e meninas pobres passam por terríveis humilhações e, como por magia, experimentam situações maravilhosas. Parte de sua obra foi retirada da literatura popular, mas muitos contos são criação do próprio escritor. Histórias como O Patinho feio, Os Cisnes Selvagens, A pequena Sereia e $A$ Rainha da Neve têm encantado várias gerações de crianças e adultos em versões alemãs, francesas, italianas, espanholas, portuguesas, brasileiras... No universo literário de Andersen, não há o ludismo, a alegria e a leveza existentes na maioria dos contos de Perrault e Grimm. Exceto os poucos momentos de bom humor, predomina, na obra desse escritor dinamarquês, um ar de tristeza ou dor, porém há uma grande ternura voltada para os pequenos e desvalidos, como na emocionante $A$ pequena vendedora de fósforos.

Atualmente, Andersen é consagrado como o verdadeiro criador da literatura infantil romântica por ter conseguido a fusão entre o pensamento mágico das origens arcaicas e o pensamento racionalista dos novos tempos. Além disso, ele é "[...] a primeira voz 


\section{Revista do SELL}

v. $4, n^{\circ} .2$

ISSN: $1983-3873$

autenticamente romântica a contar histórias para as crianças e a sugerir-lhes padrões de comportamento a serem adotados pela nova sociedade que naquele momento se organizava." (COELHO, 2003, p. 25, grifo do autor).

Dentre os valores expressos na obra de Andersen, estão os de espírito cristão e os do espírito liberal-burguês. No primeiro, há a exaltação de virtudes como a paciência, a resignação, o amor, a obediência, o recato, a caridade e a necessidade do ser humano atravessar o "vale de lágrimas" para chegar ao céu. Já em relação ao espírito liberalburguês, as histórias de Andersen enalteciam o individualismo generoso e empreendedor, a igualdade entre os homens, a fraternidade e o paternalismo dos ricos para amenizar o sofrimento dos pobres.

O avanço do racionalismo cientificista e o pragmatismo da sociedade progressista provocaram uma gradativa marginalização do maravilhoso dos contos de fadas, de natureza sobrenatural ou mágica. Por isso, a obra da Condessa de Ségur Novos contos de fadas (França-1856), que tentava unir o maravilhoso feérico arcaico com o racionalismo moderno, fracassou no interesse do público. Entretanto, a autora conseguiu sucesso absoluto com Meninas exemplares, também de 1856, ao se voltar para a vida real e ir forjando, com muito bom humor, os modelos de conduta que deveriam ser seguidos por suas jovens leitoras.

$\mathrm{Na}$ década seguinte, no lugar do maravilhoso feérico, sobrenatural, começa a fazer sucesso o fantástico absurdo, como Alice no País das Maravilhas, de Lewis Carroll, publicado na Inglaterra em 1865. Uma outra vertente foi a fusão do maravilhoso dos contos de fadas com o racionalismo realista dos contos exemplares em Pinóquio, publicado em 1883 na Itália por Collodi. Nesta obra, diante do pensamento positivista e da orientação educacional da época, o maravilhoso feérico é usado como instrumento do racional e a história do boneco de madeira transforma-se em um divertido manual de conduta para as crianças da sociedade progressista.

$\mathrm{Na}$ sequência, por várias décadas, o conto de fadas e o conto maravilhoso entraram em recesso, mas voltam a ser descobertos no século XX na área do simbólico, como fonte de conhecimento das vivências humanas. Em pleno século $\mathrm{XXI}$, a magia do maravilhoso está de volta. Multiplicam-se, nas livrarias, no cyberespaço e nas telas de cinemas, edições clássicas e novas versões dos contos de fadas ou contos maravilhosos, lendas e mitos. Isso pode ser verificado por meio do sucesso de público dos contos de fadas modernos Harry Potter e Shrek. Neste último, em meio a paródias de personagens clássicos, há a exteriorização de valores básicos, como a amizade entre o ogro e o burro 


\section{Revista do SELL}

v. $4, n^{\circ} .2$

ISSN: $1983-3873$

falante, a beleza interior de Shrek e o amor verdadeiro entre este protagonista e a princesa Fiona.

Os contos de fadas continuam vivos, venceram a barreira do tempo e estão à disposição em livros impressos e digitais, filmes, CD-ROM e outras multimídias. Independente do suporte, esses contos vêm encantando pela arte literária, pelo maravilhoso e, ao mesmo tempo, fornecendo subsídios para a formação de valores das novas gerações.

\section{O maravilhoso e a formação dos valores morais: outros olhares}

Como já foi dito, os contos de fadas têm sido fonte de estudo para especialistas de diversas áreas. Ao fazer uma correlação analógica entre as coordenadas do universo literário e do universo humano propostas pelo etnólogo e folclorista Wladimir Propp, é possível compreender a fascinação que esses contos têm sobre o espírito humano. Mas apesar de Propp (1992) ter aberto o caminho para uma renovação dos estudos dos contos, a partir de uma nova proposta de análise estrutural e das significações do conto fantástico russo, foram os estudos centrados na psicanálise de Jung, Freud e Bettelheim que difundiram no ocidente uma certa maneira de abordar os contos de fadas.

A partir da década de 80 do século XX, os psicólogos infantis passaram a valorizar os contos de fadas, utilizando-os na terapia de crianças para ajudar a resolver problemas, levando-as à reflexão sobre os acontecimentos que se desenrolam nos contos. Dessa forma, elas encontram nos contos de fadas valores humanos éticos e morais, o que as leva a uma identificação com as personagens do bem e ao desejo de vencer o mal. No processo de mediação de valores:

O desejo de corresponder a uma imagem de "homem de bem" ou "mulher de bem" gera a preocupação com o chamado imago social. Desse desejo de corresponder a uma imagem social do "bem", surge um medo de ser rejeitado pelo grupo e de ser diferente. A sombra, na conceituação proposta por Jung, contém os aspectos ocultos, reprimidos e desfavoráveis do homem. Para ultrapassar a limitação, o ego entra em conflito com esta sombra a fim de enfrentar a não aceitação de características pessoais socialmente mal vistas. (OLIVEIRA, 2013, on-line, grifos do autor).

Por outro lado, os psicanalistas freudianos preocupam-se em mostrar que tipo de material reprimido ou inconsciente está subjacente nos contos de fadas e como estes se 


\section{Revista do SELL}

v. $4, n^{\circ} .2$

ISSN: $1983-3873$

relacionam aos sonhos e devaneios. Para Bettelheim (1980), os contos de fadas falamnos na linguagem de símbolos que representam conteúdos inconscientes. Seu apelo é simultâneo à nossa mente consciente e inconsciente, a todos os seu três aspectos - $i d$, ego e superego - e à nossa necessidade de ideais de ego também. No conteúdo dos contos, os fenômenos internos psicológicos recebem corpo de forma simbólica.

Nesse sentido, os contos de fadas podem contribuir para formação de valores, porque a criança imagina que sofre com o herói suas provas e tribulações, e triunfa com ele quando a virtude sai vitoriosa e o mal é derrotado. A criança faz tais identificações por conta própria, e as lutas interiores e exteriores do protagonista imprimem moralidade sobre ela (BETTELHEIM, 1980). Portanto, não cabe ao leitor (ou contador de histórias) adulto explicar os significados e as lições de moral veiculados pelos contos de fadas. A própria criança, leitora ou ouvinte, deve apreender os significados e valores veiculados por esse gênero literário.

Além disso, o maniqueísmo que divide as personagens desses contos em boas ou más, belas ou feias, poderosas ou fracas, auxilia a criança na compreensão de certos valores básicos da conduta humana ou do convívio social. Essa dicotomia, se transmitida na infância (até os nove ou dez anos) por meio de uma linguagem simbólica, não será prejudicial à formação da consciência ética, pois para a Psicanálise, a criança é levada a se identificar com o herói bom e belo, não devido à sua bondade ou beleza, mas por sentir nele a própria personificação de seus problemas infantis: seu inconsciente desejo de bondade e beleza e, especialmente, sua necessidade de proteção e segurança (COELHO, 1984).

Sobre a presença do mal nos contos de fadas, ele é tão onipresente quanto as virtudes. Para Cashdan, cada um dos principais contos de fadas é único, à medida em que trata de uma predisposição falha ou doentia do eu. Após o era uma vez em um lugar muito distante, os contos falam de vaidade, gula, inveja, luxúria, hipocrisia, avareza ou preguiça - os sete pecados capitais da infância. "Embora um determinado conto de fadas possa tratar de mais de um 'pecado', em geral um deles ocupa o centro da trama." (2000, p.28, grifo do autor). Isso pode ser visto na vaidade da Rainha Malvada em Branca de Neve e na inveja das irmãs de Cinderela.

Em praticamente todos os contos de fadas, o mal recebe corpo na forma de antagonistas e suas ações. Na ficção, ao contrário da vida real, essas personagens, geralmente, são boas ou más, sem meio termos. Essa polarização, ao invés de prejudicar a criança, auxilia-a na compreensão da diferença entre virtudes e maldades, o que seria 


\section{Revista do SELL}

v. $4, n^{\circ} .2$

ISSN: $1983-3873$

mais difícil se as personagens fossem representadas com a relatividade e a ambiguidade dos seres humanos. Para Bettelheim (1980), as ambiguidades e complexidades devem esperar até que esteja estabelecida uma personalidade relativamente firme na base de identificações positivas.

Além disso, Coelho lembra que a criança incorpora os valores que desde sempre regeram a vida humana, cabendo a cada sociedade decidir o que seriam virtudes ou desvios de caráter. Para essa autora:

[...] o que a criança encontra nos contos de fada são, na verdade, categorias de valor que são perenes. Impossível prescindirmos de juízos valorativos: A vida humana, desde as origens, tem-se pautado por eles. $\mathrm{O}$ que muda é apenas o conteúdo rotulado de "bom" ou "mau", "certo" ou "errado" ( COELHO, 1984, p. 34, grifos do autor).

Em termos éticos, a Teoria da Virtude, inspirada em Aristóteles, reconhece que diferentes tipos de permutações de virtudes podem ser encontrados em diferentes espaços sociais e que cada sociedade deveria promover as virtudes que valoriza. Dessa forma, os antigos gregos valorizavam particularmente a coragem, ao passo que os cristãos medievais valorizavam a castidade. (WINCH; GINGELL, 2007, p.212). Nessa perspectiva, isso implica dizer que, apesar de variações em relação a cada época e país, as virtudes básicas externadas nos contos de fadas são comuns em muitas sociedades, apenas umas são mais valorizadas do que as outras.

Assim sendo, por falar das emoções que toda criança vive e porque a humanidade continua hoje com a mesma necessidade de acreditar em forças mágicas para poder explicar o que acontece em seu particular e a todos em geral, é que os contos de fadas têm atravessado fronteiras geográficas e perpetuado por milênios. Porque essa forma literária, segundo Benjamin (1980), é hoje o conselheiro das crianças, porque foi antes o primeiro da humanidade. Sobre essa dimensão utilitária da narrativa, esse mesmo autor esclarece:

Tudo isso esclarece a natureza da verdadeira narrativa. Ela tem sempre em si, às vezes de forma latente, uma dimensão utilitária. Essa utilidade pode consistir seja num ensinamento moral, seja numa sugestão prática, seja num provérbio ou numa norma de vida - de qualquer maneira, o narrador é um homem que sabe dar conselhos. (BENJAMIN, 1996, p. 200). 


\section{Revista do SELL}

v. $4, n^{\circ} .2$

ISSN: $1983-3873$

\section{As moralidades em Cinderela e As Fadas, de Perrault}

O francês Charles Perrault (1628-1703), escritor e advogado de prestígio, autor de diversos livros para adultos, tornou-se célebre e imortal por seu único volume de contos para crianças. Suas histórias foram recolhidas junto ao povo, respeitando o que tinham de cruel, de moral própria e de poético, com a intenção de recriar o maravilhoso popular. No início de sua produção literária, o trabalho de Perrault era voltado para o público adulto, os argumentos dos seus contos eram centrados em mulheres injustiçadas, ameaçadas ou vítimas, confirmando seu apoio à luta feminista na defesa dos direitos intelectuais e sentimentais das mulheres. Foi somente a partir de 1697, ano de lançamento de Histórias ou contos do tempo passado, com moralidades, que o autor manifestou sua intenção de produzir uma literatura para crianças, conforme afirma Coelho (1987, p. 68):

A partir daí Perrault volta-se inteiramente para essa redescoberta da narrativa popular maravilhosa, com um duplo intuito: provar a equivalência de valores ou de "sabedoria" entre os Antigos Greco-latinos e os Antigos nacionais, e, com esse material redescoberto, divertir as crianças, principalmente as meninas, orientando sua formação moral.

Essa produção voltada para a formação moral das meninas da França do século XVII é facilmente percebida nas produções de Perrault. $O$ enredo do conto de fadas Cinderela, apesar de possuir aproximadamente trezentas versões, segue a mesma linearidade até hoje, isto é, a heroína é humilde, faz serviços domésticos, cuida do borralho da lareira, sofre nas mãos da madrasta e das irmãs, até encontrar redenção pelas mãos da Fada-madrinha e pelo casamento com o Príncipe. Na versão de Perrault, nada se sabe sobre o pai de Cinderela, que exerce um papel insignificante, e a mãe biológica faleceu. Entretanto, a madrasta e as irmãs postiças têm grande destaque na trama. Bettelheim (1980) salienta que antes de Perrault escrever o conto Cinderela ou Gata Borralheira, o termo "viver entre as cinzas" simbolizava o rebaixamento de um irmão em detrimento de outro, independentemente do sexo dele. Também afirma que o termo era atribuído a qualquer empregada suja, de condições precárias, cujo ofício era limpar as cinzas da lareira.

Após essa narrativa, como era peculiar em suas Histórias e contos do tempo passado, com moralidades (1697), obra conhecida também como Contos de Mamãe Gansa, o autor acrescentou as seguintes moralidades em forma de versos: 


\section{Revista do SELL}

v. $4, n^{\circ} .2$

ISSN: $1983-3873$

\section{Moral}

Na mulher a beleza é um raro tesouro,

De admirá-la ninguém cansa jamais;

Mas chamamos de graça algo que mais

Valor ainda tem prata ou ouro.

Foi o que à Cinderela ofertou a Madrinha,

Dando-lhe trato e instrução,

Tanto que dela fez uma rainha.

(Assim é deste Conto a Moral ou Lição.)

Beldades, vale mais que estar bem penteadas,

O dom da graça para prender um coração,

É este, na verdade, o dom das Fadas;

A graça pode tudo, o resto é ilusão.

\section{Outra moral}

Por certo é uma grande vantagem

Ter inteligência e coragem,

Ser bem nascido, ter bom senso,

E outros dons mais, em rol imenso

Que o Céu nos dá como quinhão,

Mas tudo isso será vão

Para na vida ter sucesso, caso não

Houver para vos dar uma mãozinha

Algum bom padrinho ou madrinha

(PERRAULT, 2007, p. 114).

Nessas moralidades, há a exaltação da graça, das boas maneiras em detrimento da beleza física. A Cinderela somente conquistou o Príncipe devido à graciosidade concedida a ela pela Madrinha. A moça encantou a todos não somente por ser linda fisicamente; mas, principalmente, pelo seu bom comportamento e pela sua boa educação: ela era gentil, dançava divinamente, sabia se portar à mesa e foi generosa inclusive com suas malvadas irmãs, oferecendo-Ihes laranjas e limões doces durante o jantar no baile e, mais tarde, levando-as para o castelo e casando-as com ilustres senhores da corte (CONTOS, 2010).

Já a história As Fadas, apesar de não ser tão popular como Cinderela, possui todos os elementos de um genuíno conto de fadas. A narrativa acontece em tempo e local indeterminados e a protagonista não tem um nome próprio, por isso, ela representa qualquer menina vítima das maldades dos familiares. Inicia-se com um problema vinculado à realidade (estado de penúria, carência afetiva, conflito entre mãe e filha, rivalidade com a irmã) que desequilibra a tranquilidade inicial. $\mathrm{O}$ desenvolvimento é uma busca de soluções, no plano da fantasia, com a interferência de uma fada, e no final, a ordem é restaurada via casamento com um príncipe. Portanto, tem como eixo gerador 


\title{
Revista do SELL \\ v. $4, n^{\circ} .2$
}

ISSN: $1983-3873$

uma problemática existencial. Segundo Coelho (1987, p.13): "Ou melhor, tem como núcleo problemático a realização essencial do herói ou heroína, realização que, via de regra, está visceralmente ligada à união homem-mulher."

Nessa produção de Perrault (2007), o narrador conta que era uma vez uma certa viúva que tinha duas filhas: a mais velha, parecida com a mãe em feições e gênio, era má e feia; já a caçula por sua doçura, gentileza e bondade era o retrato do pai. Por isso, a mãe tinha uma enorme aversão pela filha mais nova e todo o trabalho doméstico era delegado para ela, inclusive ir duas vezes por dia buscar água em uma fonte que ficava a duas léguas de distância da casa delas. Um dia quando a heroína estava na fonte, apareceu uma fada disfarçada de pobre mulher e pediu água para ela. Muito gentil, a bela moça disse "Pois, sim, minha boa senhora", e serviu a água. Como recompensa, a Fada concedeu-Ihe o seguinte dom: "[...] a cada palavra que disserdes, saia de sua boca uma flor e uma pedra preciosa." Ao voltar para casa, a cada gentileza dita pela moça, saiam rosas, pérolas e diamantes de sua boca. Espantada, a mãe quis saber a razão disso e logo enviou sua filha mais velha para a fonte. Mas esta muito mal-educada insultou a Fada que the pediu água e, como castigo, a cada falar da moça, saiam serpentes e sapos horrendos de sua boca. Ao ver isso, a mãe expulsou a heroína de casa e esta empreendeu uma longa e penosa viagem até encontrar o filho de um rei, que vendo sua beleza, sua gentileza e de sua fala sair joias, casou-se com ela.

Após a narrativa, Perrault (2007, p.107) acrescentou as seguintes morais:

\author{
Moral \\ As pístolas e os Diamantes \\ Podem as Mentes fascinar; \\ Mas as palavras confortantes \\ Têm ainda mais força, e um valor sem par.
}

\section{Outra Moral}

A honestidade exige alguns cuidados,

E quer também alguma complacência, Mas cedo ou tarde tem sua recompensa,

$\mathrm{E}$ em momentos até os menos esperados.

Nessas morais, há a valorização da gentileza (palavras confortantes), dom mais precioso que quaisquer diamantes ou pístola (antiga moeda francesa que valia dez francos). A mulher que tiver um falar doce e for honesta será recompensada com um bom casamento quando ela menos esperar.

É possível também perceber um maniqueísmo latente nos dois contos. Em ambos, a heroína é doce, gentil, bela, bondosa e educada. Já as vilãs - mãe/madastra e irmãs - 


\section{Revista do SELL \\ v. $4, n^{\circ} .2$ \\ ISSN: $1983-3873$}

são feias, invejosas, mal-educadas e delegam à "mocinha" todos os afazeres domésticos. Assim sendo, entre os valores ético-sociais realçados em Cinderela e As Fadas, podem ser citados o servilismo atribuído aos trabalhos domésticos, a exaltação da beleza e das qualidades essenciais à mulher do século XVII: submissão, bondade, cortesia, gentileza. Há também a importância do falar educado e cortês, além da recompensa (um bom casamento) como estímulo às virtudes.

Por fim, vale dizer que, nessas duas narrativas, tal como acontece em diversos outros contos de fadas, as outras personagens da história não têm nomes próprios. A mãe, a madrasta, as irmãs, o rei, o príncipe, todos são colocados de forma anônima. Isso indica que não somente as protagonistas da história poderiam ser qualquer garota, como também as outras personagens poderiam ser outras pessoas. A história não se refere exclusivamente a um grupo, ela se coloca como se pudesse acontecer com qualquer ser humano. Assim sendo, o conto de fadas pode viabilizar que a própria criança, ouvinte ou leitora do conto, projete-se na história. Desta forma, Cinderela e a heroína de As Fadas poderiam se chamar Maria, Stephanie, Nicole, Natasha, ou até mesmo ser personificada em um menino que sofresse, em sua infância, dilemas semelhantes.

\section{Considerações finais}

Este estudo não pretendeu de forma alguma desmerecer o caráter maravilhoso dos contos de fadas. Como já foi dito, sabe-se que o encantamento desse gênero reside na magia, na fantasia, na obra de arte literária. O que se buscou aqui foi voltar o olhar para seu aspecto moralizante, estabelecendo um diálogo, sobretudo, entre Literatura, Psicologia, Psicanálise e Semiologia. Para isso, buscou-se respaldo nos trabalhos de estudiosos dessas diferentes áreas, como Todorov, Coelho, Benjamin, Bettelheim, Freud, Yung e Propp, dentre outros.

Procurou-se desenvolver um estudo, apresentando uma pesquisa bibliográfica sobre alguns conceitos elementares, a história sociocultural desse gênero literário e a visão de alguns especialistas sobre o tema em questão. Por fim, realizou-se uma breve análise das moralidades expressas nos contos Cinderela e As Fadas, de Charles Perrault.

Contudo, é importante dizer que toda a riqueza dos contos de fadas fica comprometida por adaptações, suavizações e alterações das versões originais por meio de edições escritas ou cinematográficas que pasteurizam os clássicos, tirando sua densidade, significação e revelação. Para Bettelheim (1980, p.12): “A aquisição de 


\section{Revista do SELL}

v. $4, n^{\circ} .2$

ISSN: $1983-3873$

habilidades, inclusive a de ler, fica destituída de valor quando o que se aprendeu a ler não acrescenta nada de importante à nossa vida."

Por fim, espera-se que este trabalho possa estimular novas análises de valores morais e éticos em outros contos de fadas clássicos e/ou modernos, seja confirmando ou refutando a abordagem adotada neste artigo. Além disso, sugere-se também uma investigação de caráter qualitativo, nas áreas de Educação e/ou Ensino de Literatura, por meio de uma pesquisa de campo para verificar se/como os contos de fadas estão sendo abordados na escola e no contexto familiar.

\section{Referências}

ABRAMOVICH, Fanny. Literatura infantil: gostosuras e bobices. São Paulo: Scipione, 1989.

BENEDETTI, Ivone, C. Apresentação. In: PERRAULT, Charles. Contos de Mamãe Gansa. Tradução e apresentação de Ivone C. Benedetti. Porto Alegre: L\&PM Pocket, 2012. p. 7-22.

BENJAMIN, Walter. Textos escolhidos. São Paulo: Abril Cultural, 1980.

. Magia e técnica, arte e política. São Paulo: Brasiliense, 1996.

BETTELHEIM, Bruno. A psicanálise dos contos de fadas. Rio de Janeiro: Paz e Terra, 1980. Rio de Janeiro: Paz e Terra, 1992.

CANDIDO, Antonio. Vários escritos. 3. ed. São Paulo: Duas Cidades, 1995.

CANTON, Kátia. Conversa com madame: Perrault nos salões franceses. São Paulo: Difusão Cultural do Livro, 1997.

CASHDAN, Sheldon. Os sete pecados capitais nos contos de fadas: como os contos de fadas influenciam nossas vidas. Rio de Janeiro: Campus, 2000.

CHALITA, Gabriel. Pedagogia do amor. a contribuição das histórias universais para a formação de valores das novas gerações. São Paulo: Gente, 2003.

COELHO, Nelly Novaes. A literatura infantil: história, teoria, análise. 3. ed. São Paulo: Quíron, 1984. . O conto de fadas. São Paulo: Ática, 1987.

. O conto de fadas: símbolos mitos arquétipos. São Paulo: DCL, 2003.

CONTOS de fadas: de Perrault, Grimm, Andersen \& outros. Apresentação de Ana Maria Machado; tradução de Maria Luiza X. de A. Borges. Rio de Janeiro: Zahar, 2010. 


\section{Revista do SELL}

v. $4, n^{\circ} .2$

ISSN: $1983-3873$

CUNHA, Maria Antonieta Antunes. Literatura infantil: teoria e prática. 5 ed. São Paulo: Ática, 1986.

OLIVEIRA, Cristiane Madanêlo de. A desconstrução do medo de bruxa na literatura infantil contemporânea. Disp. em: http://www.graudez.com.br/litinf/trabalhos/terror.htm. Acesso em: 15 maio 2013.

PERRAULT, Charles. Contos e fábulas. Tradução e posfácio de Mario Laranjeira. São Paulo: lluminuras, 2007.

PROPP, Wladimir. Morfologia do conto. 3. ed. Lisboa: Veja, 1992.

TODOROV, Tzvetan. A narrativa fantástica. In: As estruturas narrativas. 2. ed. São Paulo: Perspectiva, 1979.

WINCH, Christopher; GINGELL, John. Dicionário de filosofia da educação. Tradução de Renato Marques de Oliveira. São Paulo: Contexto, 2007. 